\title{
Ezzat Hegazy: an Eminent Father of Social Gerontology in The Arabic World
}

\author{
Ahmed Shawky Mohammedin* and Shaimaa Nabil Rohaiem* \\ *Geriatrics \& Gerontology department, Faculty of Medicine, Ain Shams University, Cairo, Egypt.
}

\begin{abstract}
Professor Ezzat Hegazy (1931-2016), was an eminent social gerontologist. He is considered to be one of the founding fathers of social gerontology in Egypt and the Arabic world. He has led a rich scientific career during his work in the National center for social and criminological research. His contributions covered multiple sociology domains, his work in social gerontology has set the foundation of Gerontology in Egypt and the Arab world leaving us with a huge Legacy of scientific achievements. This article is an attempt to register his effort and contributions as a role model for young gerontologists.
\end{abstract}

Keywords: Ezzat Hegazy, Gerontology, Ageing, Egypt

\section{Background:}

This article is not about a single person, it is about a whole generation, indeed. It is a trial to document the work of Professor Ezzat Hegazy as a successful model of his generation. His sincere efforts in establishing the Egyptian sociology science should be considered as an example to follow

\section{Early life:}

Mohammed Ezzat Selim Hegazy (1931-2016) (Arabic: (محم عزت حجازي or simply Ezzat Hegazy was born in Sharqyia governorate, kingdom of Egypt in 1931 (1) ${ }^{\mathrm{i}}$. He was raised in a rural environment; this must have driven his interest and awareness of social life development. Throughout his scientific career, this was reflected in his lifelong works.

\section{Educational and scientific foundation:}

He enjoyed the highly esteemed Egyptian education in the pre-1952 revolution era. During this period the Egyptian nation was investing many resources in education. One quote by Taha Hussain (1889-1973) the famous Egyptian academic, writer, social reformer and then Minister of Education: "Education is like water and air, essential for life" $(2)^{\mathrm{ii}}$.

Hegazy had witnessed lots of social and political turmoil in Egypt at that period. After finishing his high school education, he was able to join Cairo University (King Fouad University back then). At the higher school of arts (now faculty of Arts), he joined the department of philosophy where he graduated in 1953 with a Bachelor of Art degree (3) ${ }^{\text {iii }}$.

Occupational carrier:

Three years after graduation he had the opportunity to join the National Center for Social and Criminological Research (NCSCR) (1). NCSCR was established in 1955 as a center of excellence for social and criminological research in Egypt (4) ${ }^{\text {iv }}$. Since its establishment, it has contributed in social development and decision support in Egypt. Nowadays, NCSCR is under the umbrella of the Egyptian ministry of social development.

NCSCR currently has more than 125 research staff with various grades. It is divided into 4 main divisions. Under each division, several research departments exist at the National Center for Social and Criminological Research (5) ${ }^{\mathrm{v}}$. Most of Professor Hegazy career was in the "Population and social categories research department" (PSCRD) under the "division of social categories and communities research". The PSCRD aims at conducting research about all social variables related to population issues in Egypt, not only on general population research, but also on special population sectors as women, elderly, and families. Prof Hegazy repeatedly said that PSCRD was his second home where he spent most of his days.. 
Scientific carrier \& foundation:

While working in NCSCR Prof Hegazy had a chance to earn his Master of arts degree from Cairo University in 1964 (1). It also seems that his MA degree was under joined supervision of University of Minnesota in 1964 (3). Then he had the opportunity to earn a PhD in Sociology major \& Anthropology minor from Minnesota University, USA in 1968 (6) ${ }^{\mathrm{vi}}$. Afterwards he returned to Egypt. He was always insisting on updating his knowledge and on continuous professional development for himself and his co-workers even after his retirement. He led holding the "Tadakhool" program executing several national training workshops (2010-2011) as a part of the elderly care development project to update the knowledge of elderly social care providers $(7)^{\text {vii }}$.

Academic and research contribution:

As an academic, Prof Hegazy was very keen to raising his contemporary standards and to build capacities of modern sociology and gerontology in Egypt as well as the Arab world. He always believed in the applied and translational research. His research touched many contemporary social dilemmas, as he tried to translate research into action in order to share in society development. He settled down in NCSCR and was one of the forefathers of social research in Egypt and the Arab world $(8)^{\text {viii }}$. His research had a major impact on social studies and development in the Arab speaking world. His books and studies are cited in various scientific articles, reports and books. Any online research would find his work present in libraries of Arabic universities and research institutes, and in some western universities (9) ${ }^{\mathrm{ix}}$.

In 1974s, he travelled to Yemen as a visiting professor at Sanaa University to help in development of social studies and research. He became the head of the sociology and philosophy department (1). He had also traveled to several Arab countries to contribute to many scientific conferences and workshops. Hegazy always mentioned that he preferred to stay in Egypt as he felt he had a mission towards his society. His academic and research activities led him to be the head of the PSCRD. As all polymaths he was "wearing many hats" and his contributions added values to his society in many domains.

The researcher and author:

After return to Egypt from Yemen he was in continuous endeavor to raise the standards of methodology and ethics of social studies research in Egypt and the Arab world. His research reflected preoccupations with finding facts, root cause analysis, and formulating solutions to the Egyptian society major social dilemmas. This is evident from the wide array of subjects of his publications (as an author and co-author)
(9).

Table 1: Prof Ezzat Hegazy major social research legacy categories
* Social Gerontology

*Social research methodology

*Social research ethics

* Social biblographic databases

*Standardization in Sociology

* Sociologic terminology

\author{
* Women sociology \\ * Youth sociology \\ * Rural areas sociology \\ * Poverty and social \\ development \\ * Urbanisation \\ * Sinai sociology and \\ development
}

His philosophy in research is documented in the various introductions and discussions in his books, articles and reports $(10)^{\mathrm{x}}$. He was very patient in research but always challenged his co-workers to bring the best out of them. He was a great mentor and a talented leader with an accurate penetrating vision. Despite limited resources (both financial and human), he continued over many decades to execute high yield studies. Whenever he wrote, he was sure to add a true significant scientific value. In any research project he was keen to get true accurate results, not just any results. Even after publishing his article or book he continued afterwards to do follow-ups and updates This is evident in his social gerontology books. This can be found in the serials of books on $2004(11)^{\mathrm{xi}} \& 0 \mathrm{n}$ 2014 (7) about Egyptian geriatrics homes, same with the Elderly daycare clubs $(12)^{\mathrm{xii}}(13)^{\mathrm{xiii}}$.

As a first-class field researcher, he wrote the "Researchers training manuals" by himself and executed research assistant training by himself. He wrote detailed research plans and insisted on supervising, overseeing field work by himself even in distant or rural areas (10). He was always present in the field work to make sure of accurate application of the research plan and rapid management of any obstacle. Hegazy always encouraged recording both success and failure stories to learn from both.

The scientific critic:

His integrity as a researcher was coupled with a continuous interest in ethics and standardization. While leading a fruitful carrier as a researcher, he was noticed to be an excellent critic with a deep penetrating vision. Besides being a straight forward, honest and tough researcher. All this nominated him to be the vice director of the "National sociological journal" (NSJ) of Egypt (Arabic: المجلة الإجتماعية القومية) (14) xiv . He held 
this position for about 30 years. NSJ is an eminent Arabic sociology journal in Egypt and the Arab speaking world. He continued to be a living example of scientific criticism and peer reviewing. He kept on guiding his students and fellow colleagues to improve their scientific products. He believed in high academic and research standards. He always tried to apply it on his own research and peer reviewing.

$\mathrm{He}$ was brave in his scientific constructional criticism of academia, governmental services, and nongovernmental services in a manner that led to improving systems. One example is his comments on the discrepancy of the Egyptian elderly population percentage in the census and other scientific reports $(15)^{\mathrm{xv}}$. Another example is his struggle to urge the governmental programs to allocate more resources and support to informal caregivers of elderly (families and volunteer caregivers). Hegazy always stated that community and home care should be the norm, not "the Geriatric homes", as more than $95 \%$ of Egyptian elderly are living in their homes (7). As a scientific critic, this has brought him some conflicts, however he always won respect from all his colleagues and students, he was an honorable model.

\section{The Gerontologist:}

His major contributions in social gerontology qualified him to become one of the forefathers of Gerontology in Egypt and the Arab world. He applied his social research philosophy to Gerontology in general and to social Gerontology specifically. There were several contributions to gerontology before him in the NCSCR. But to the author's knowledge, he was the first major researcher and author in gerontology in the Arabic world. He produced many publications covering elderly demographics, elderly levels of care, and several elderly services (16) xvi . As he believed in multidisciplinary teams, he was keen to interact with the pioneers of Geriatric medicine Prof Abdel-Moneim Ashour, and Prof Mohammed Sabbour, nursing gerontology, psychological gerontology among other pioneers in Egypt and the Arab world. these sustained efforts helped in setting the scene for appearance of specialized services and academic programs for elderly. To our knowledge, his first published contribution to Gerontology was in 1999 (9). He was fond of filling the knowledge gaps regarding elderly care in Egypt. These gaps included basic elderly demographics $(17)^{\text {xvii }}$, rural elderly (10), elder abuse $(18)^{\text {xviii }}(19)^{\text {xix }}$, the spouse old caregiver, elders as grandchildren's caregivers, elderly use of technology, and elderly use of Social media among other gaps of knowledge (13).

He was keen to investigate the situation of elderly care in all settings. He was networking with researchers from all over Egypt. He believed that improving elderly services is possible only through evidence-based approach. Sometimes he suffered from red tape and saw it suffocating research and limiting creation. But he never lost his faith or felt helpless. He always sought alternatives targeting near perfection. Although his primary specialization was sociology, but he was an avid well-informed reader and a friend to technology, he always kept himself updated by using the internet.This has helped him to become a "true" gerontologist, as gerontology was a mysterious branch in its early begainnings. Anyone that has worked with him must have noticed his huge fund of knowledge about gerontology, and its subsidiaries including psychology, healthcare, legislation, economics, and even biological Gerontology. Indeed, he was a great polymath.

The Elderly care development project:

Prof Hegazy was visionary about the rising challenges facing elderly care in Egypt. He tried to draw a road map for improving elderly social care in Egypt. The road map was translated into action by the elderly care development project (ECDP) (2008-2012) (Arabic: (مشروع تطوير رعاية المسنين (20) (20) . The ministry of social solidarity in 2008 delegated Prof Hegazy \& NSCR to lead efforts to improve the Egyptian elderly care. Hegazy was trying to drive improvement of elderly care by the ECDP. He led establishing a general database for elderly in Egypt. Next, he contributed to the updating of the standards for Geriatrics homes $(21)^{\mathrm{xxi}}$, daycare centers (elderly clubs) (22) xxii , and community physiotherapy units for elderly $(23)^{x x i i i}$. He also drove the drafting of the first Social home care standards in $2010(24)^{\text {xxiv }}$. These drafts have helped in developing updated standards drafts in 2014.

He published the Elderly care database book in 2006 (16). Then he was the initiator of the "National elderly care network database" (NECND) in 2010 (table 2). It was summarized in a hard copy preliminary database including known providers and actors of elderly care in Egypt (both social and health care). It included the available governmental, non-governmental (for profit or not for profit) and other organizations sharing in elderly care provision. All were subcategorized according to their contribution(s) into governance, standards, academia, human resources, and all levels of care. The aim was to support decision taking; elderly and their caregivers; networking of providers; building capacities by sharing success stories; plus learning from both successful and unsuccessful experiences.

The authors and Dr Mohammed Fahmy Tolba collected and wrote the paper-based hard copy database of the known healthcare related services at that time. However, it was not published. There were several trials with Prof Hegazy help, to make it available in a soft copy through an online website, but with no success. Later on in 2014 "Wikiageing.org" ويكيتعمر (the knowledge management tool) was established aiming at translation of knowledge into action in all domains of elderly care $(25)^{\mathrm{xxv}}$. It is a voluntary open source 
project based on an online website. It is run mainly by academia from Geriatrics, gerontology and other elderly care providers. Prof Hegazy agreed to use some data from the NECND and the updated elderly care standards and home care standards drafts to Wikiageing. These data were part of the nucleus that shaped Wikiageing.

Prof Hegazy was interested in raising awareness about the "Social network capital" concept (family \& friends) as a mainstay of social care (7). He always emphasized this concept in his writings about elderly care in the ECDP. He believed that growth of the social network capital (SNC) is one of the main assets and solutions to the dilemmas facing elderly care. He was always advising to monitor it and preventing its atresia due to any cause. Hegazy viewed investing in SNC as the best method to keep the elderly functioning and independent. We have also translated and adapted an Arabic version of Leuben Social network scale (26) ${ }^{\text {xxvi }}$ to help to assess this asset.

As an academic shaped during the golden era of Egyptian academia 1950-1960s, he was very fluent in Arabic language among other languages. His respect to the "Modern standard Arabic" was translated in his urge to standardize scientific terminology in Arabic for Sociology (27) ${ }^{\mathrm{xxvii}}$ and Gerontology (10). During the ECDP he encouraged collecting scientific terminologies and definitions and adapting them to Arabic. He has initiated efforts to collecting terminologies related to Geriatrics and Gerontology. Prof Hegazy had previously authored and co-authored dictionaries about social sciences terminologies (Arabic, English, and French) $(28)^{\text {xxviii }}$. He was always meticulous in translating or adapting terminologies. He was careful in choosing Arabic wording or creating or crafting a new Arabic word to indicate new meanings.

For example, he adopted translating "gerontology" in Arabic as "Ta'ammor" "تعمُر in all his writings. To our knowledge, this terminology was first used in 1997 by Shehata, M (29) ${ }^{\text {xxix }}$. Then it was also used by $\mathrm{Dr}$ Mahran, M and Naguib M book in 1999 (30) ${ }^{\mathrm{xxx}}$. While other authors translated it into more classic wordings as "Tashayyoukh "تشيخ", and "E'amar but these classic wordings carry a stigma وصمة or is non-specific. Also, "E'maar" is used in urban and architecture sciences (15). He was bold and innovative in his approach in encouraging scientific creativity. We hope all academia in gerontology would follow his track to manage the issues of terminologies and stigmas related to Ageing.

Prof Hegazy was innovative in tackling nonconventional gaps of elderly care. Including agefriendly environmental design; initiating the "elderly domiciliary services offices" at the elderly clubs (15) (31) ${ }^{\text {xxxi }}$; companion-ship marriage (32) ${ }^{\text {xxxii }}$; and standardization of home care (24). He tried to establish a governance system to regulate home care services in Egypt. Currently, the services are provided by a mixture of providers (mainly non-governmental organizations (33) ${ }^{\text {xxxiii }}$, religious organizations, some for-profit organizations, and rarely by governmental programs). Each service is adopting its own ways of care and concepts. Also, he tried to change the registration of home care providers in the official working registration lists from the "home servants" current category to the new proposed category of "home care aids" (15). He believed this would remove one of the obstacles of development of home care services in Egypt.

Table 2: Components of the elderly care development project (2008-2012) (7) (13)

- Building the Egyptian elderly database

$\begin{array}{cl}\circ & \text { Ageing in Egypt } \\ \circ & \text { Statistics of elderly (>60y) } \\ \circ & \text { Geriatric homes list } \\ \circ & \text { Daycare elderly clubs list } \\ \circ & \text { Elderly services offices } \\ \circ & \text { Laws governing elderly care } \\ \circ & \text { NGOs providing services for elderly }\end{array}$

- Standardization of care (draft standards of Geriatric homes, Daycare, social home care, \& physiotherapy units)

- "Tadakhol" educational \& training program for social elderly care providers

Publications:

- Hegazy E, et al. (2009): Elderly care in Egypt - reality \& targeted.

- Hegazy E (2009): Action plan for elderly care in Egypt

- Hegazy, E (2014): Geriatric homes in Egypt - a full survey

- Hegazy, E (2014): Elderly daycare clubs in Egypt - a full survey

- Hegazy, E (2017): National network of non-governmental organizations for elderly care (34)

Suggested surveys: (Home care aids pilot study \& elderly care status at homes).

National elderly care network database 
Figure 1: Prof Ezzat Hegazy at one of his visits to Ain Shams geriatrics \& gerontology department on 13 November 2014 (source: wikiageing.org - ashashyou creative commons license)

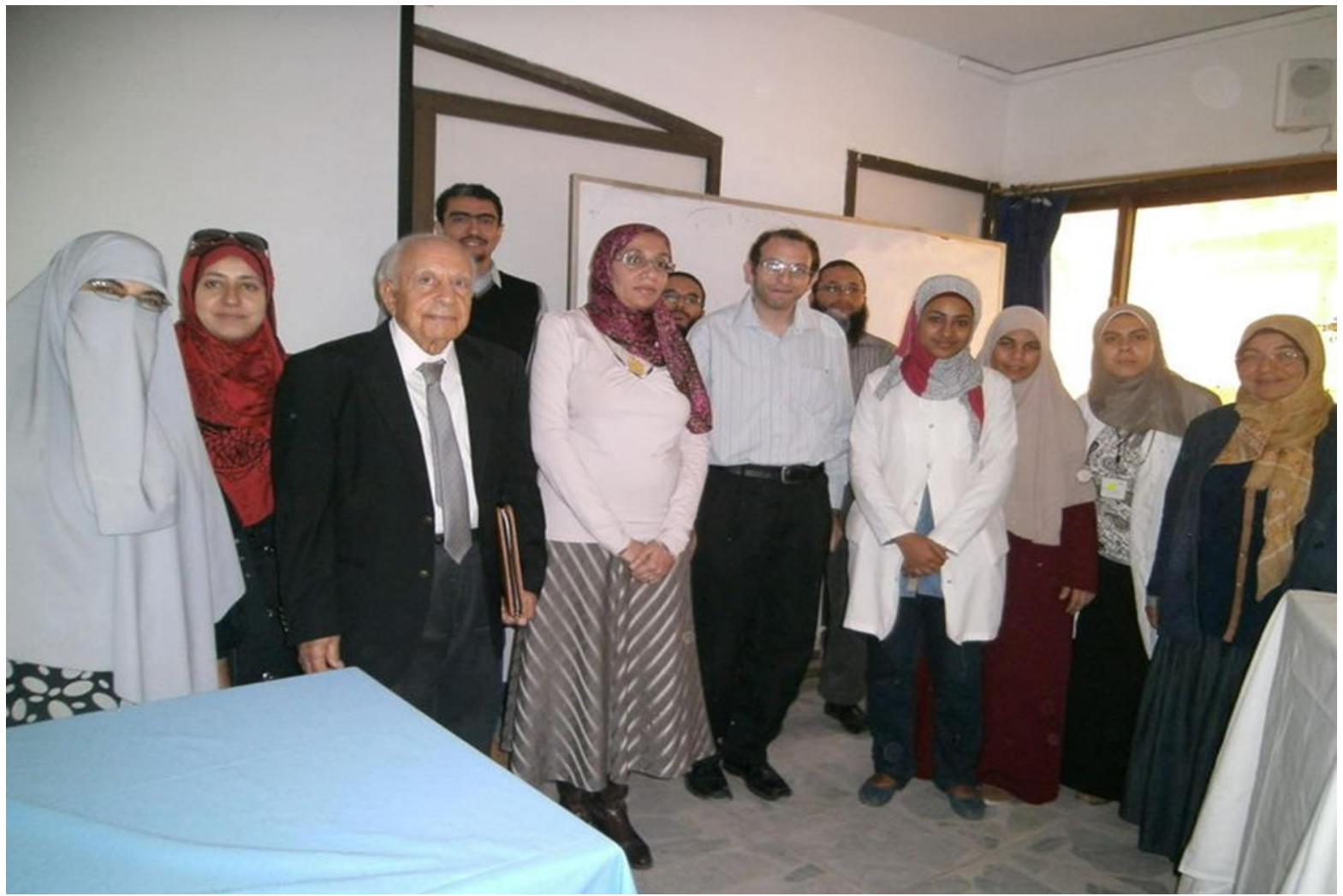

The "active ager" in a silver workforce:

Despite reaching the official retirement age, Prof Hegazy continued to work. He kept on working as a Tenured Professor then as an Adjunct Professor. He was a living example of active ageing. He continued to work in NCSCR until the last weeks of his life. In his last months he wrote an article about peer reviewing culture among social sciences academics. One of his last projects was a piolet study about the situation of Elderly Egyptians care in family residencies. Despite suffering from some health issues, he insisted on going to his office 3 times weekly. Moreover, he occasionally attended extra meeting outside his working days. Even when he stopped going to his office, he continued following conducting the research study by telephone. He was a role model of the dedicated scientist.

\section{Honoring:}

He was very modest in his relationships. He didn't care for the lights of media or public life. Despite this he wasn't enclosed on himself, he cooperated with many media people \& journalists. He made a lot of statements to Arabic and English journals (10) to raise awareness about certain issues of ageing. He resisted nomination to be a member of the academic promotion committee of the NCSCR. Hegazy felt it would consume a lot of his time by routine or red tape blocking his scientific contribution.

His efforts were very much appreciated by academia. To our knowledge, he was honored for his efforts in advancement of sociology and Gerontology. He was honored twice by the Ain Shams Geriatrics and Gerontology department in its 2nd and 3rd international conferences. NCSCR honored him as one of its pioneers in 2015 (8) and again after his death.

He won the respect of his colleagues, students, coworkers, and above all the Egyptian Elderly and their care givers.

\section{Legacy:}

He left us on 2016 with a huge scientific legacy. He was an encyclopedic polymath. He left us articles, reports and books in various fields (see his page on wikageing.org). After his death, his last works were published in a collective book (34) $)^{\mathrm{xxiv}}$. His legacy and scientific heritage is shared in multiple libraries in 
universities or research institutes. Including France, Iran, Egypt, Algeria, Tunisia, Morocco, Qatar, Jordan, Syria, United Arab Emirates, Palestine, Kuwait, Saudi Arabia, Iraq, Sudan, Bahrain, and Yemen). He was a standing role model of integrity in science and research. Being an "active ager" reflects his scientific believes. We hope this biography would inspire the new generations to advocate for elderly.

Hint \& Declaration:

The first author had the honor of working with Prof Hegazy and knowing him closely during the period 2008-2016. We couldn't reach the title of the MA thesis of Prof Hegazy. We would appreciate if someone can provide it. All the list publications in his page on wikiageing.org are what could be reached after extensive research. However, it is likely that other research and scientific works exists. We would appreciate updating the list.

\section{References:}

1. 'Hegazy, E (1985): Arabic Youth and their problems. Alam al-Marefa series, National council for culture, arts \& literature Kuwait (in Arabic).

2. ii Galal, A (1993): Taha Hussein (1889-1973) Prospects: the quarterly review of comparative education (Paris, UNESCO: International Bureau of Education), vol. XXIII, no. 3/4, 1993, p. 687-710.

3. iii University of Minnesota (1968): March Commencement, Saturday evening, March 16 Northrop Memorial Auditorium, Minnesota https://conservancy.umn.edu/bitstream/1129 9/57598/1/1968-commencement.pdf accessed on 11-12-2018

4. iv National Center for Social and Criminological Research (2018a): NCSCR, official website http://www.ncscr.org.eg/detailes.php?module =topic\&id=26 accessed 11-12-2018

5. National Center for Social and Criminological Research (2018b): NCSCR, official website http://www.ncscr.org.eg/detailes.php?module =topic\&id=18 accessed 11-12-2018

6. "' Hegazy E \& Martindale DA (1968): CrossCultural Experience and Social Change: The Case of Foreign Study. PhD thesis in Sociology major, Anthropology minor. Doctoral Dissertation, University of Minnesota. Dissertation Abstracts International, 1969, 29, 3679A., Minnesota

7. vii Hegazy, E (2014a): Geriatric homes in Egypt - a full survey. National Center for Social and
Criminological Research (NCSCR), Cairo (in Arabic) ISBN: 9789773092320

8. viii Qandil S (2015): The national center for sociological \& criminological research honors it pioneers. Veto gate http://www.vetogate.com/1481192 accessed on 3-11-2018

9. ix Wikiageing.org (2018a): Ezzat Hegazy http://wikiageing.org/index.php/حجازي عزت accessed on 11-12-2018

10. ${ }^{\mathrm{x}}$ Hegazy, E (1999): Elderly in rural Egypt - field study at Ekhtab village, Aga municipality of Dakahlayia governorate National Center for Social and Criminological Research (NCSCR), Cairo (in Arabic) ISBN: 8977-309-0078

11. ${ }^{\mathrm{xi}}$ Hegazy, E (2004): Elderly in Egypt - a sample survey from Geriatric homes. National Center for Social and Criminological Research (NCSCR), Cairo (in Arabic) ISBN: 9773090914

12. ${ }^{\text {ii }}$ Abd Abdel-Aal S \& Al-Arqan M (1996): Evaluation of elderly clubs. National Center for Social and Criminological Research (NCSCR), Cairo (in Arabic) ISBN: 9789773092337

13. xiii Hegazy, E (2014b): Elderly daycare clubs in Egypt - a full survey. National Center for Social and Criminological Research (NCSCR), Cairo (in Arabic) ISBN: 9789773092337

14. xiv National Center for Social and Criminological Research (2018c): National sociological journal of Egypt (المجلة الإجتماعية (القومية

https://search.mandumah.com/Record/31159 8 accessed 11-12-2018

15. ${ }^{\mathrm{xv}}$ Hegazy, E (2009): Elderly care in Egypt reality \& targeted. National Center for Social and Criminological Research (NCSCR), Cairo (in Arabic) ISBN: 9784113091813

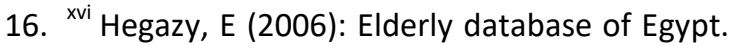
National Center for Social and Criminological Research (NCSCR), Cairo (in Arabic) ISBN: 9773091538

17. xvii Hegazy, E (2000): Elderly in Egypt comparative study of part of national census of 1986 \& 1996. National sociological journal 37 (2) Pp 1-52 (in Arabic)

18. xviii Hegazy, E \& Abdel-Kareem, A (2002): Elder abuse. $4^{\text {th }}$ Annual conference of the National Center for Social and Criminological Research (NCSCR). $2^{\text {nd }}$ conference documents Pp 701722, Cairo (in Arabic) MD: 123650 
19. xix El-Saaty, A (2010): Hotline for elderly protection \& assistance from elder abuse. Ahram newspaper 45063 (134) P1 Cairo (in Arabic)

20. ${ }^{x x}$ Egyptian Ministry of Social affairs, official website (2011): 2011 annual report http://www.moss.gov.eg/misa/Portals/0/Docu ments/\%D8\%A7\%D9\%86\%D8\%AC\%D8\%A7\%D 8\%B2\%D8\%A7\%D8\%AA\%202011.pdf accessed on 15-10-2014

21. ${ }^{x x i}$ Mohammedin, A, Siam E \& Hegazy, E (2010): Draft report on standards of elderly care programs in Geriatric homes. National Center for Social and Criminological Research (NCSCR), Cairo. (in Arabic)

22. xxii Mohammedin, A \& Hegazy, E (2010a): Draft report on standards of elderly daycare programs (Elderly clubs). National Center for Social and Criminological Research (NCSCR), Cairo. (in Arabic)

23. xxiii Mohammedin, A \& Hegazy, E (2010b): Draft report on standards of elderly social home care programs. National Center for Social and Criminological Research (NCSCR), Cairo. (in Arabic)

24. ${ }^{\text {xxiv }}$ Mohammedin, A \& Hegazy, E (2010c): Draft report on standards of physiotherapy units in Geriatric homes. National Center for Social and Criminological Research (NCSCR), Cairo. (in Arabic)

25. ${ }^{x x v}$ Wikiageing.org (2018b): Home page http://wikiageing.org/ accessed on 11-122018

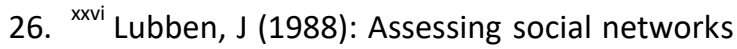
among elderly populations. Family \& Community Health: The Journal of Health Promotion \& Maintenance, 11, 42-52.

27. xxvii Hegazy, E (1971): About translating sociological sciences terms. Contemporary thought journal 77 (1) pp57-62 (in Arabic)

28. xxviii Hegazy, E \& Badawy A (1976): Dictionary of Sociology terms (Arabic - English - French). Al-Lisan al-Arabi journal 13 Pp 328-335 (in Arabic)

29. ${ }^{x x i x}$ Shehata, M (1997): Demographic ageing in Egypt. MSc thesis, Biodemographic department of the Institute for statistical studies \& research, Cairo university - Cairo

30. ${ }^{x x x}$ Mahran $M$ \& Naguib M (1999): Demograageing in Egypt - its start \& consequences. National population council, Cairo

31. ${ }^{x x x i}$ Ministry of social solidarity (2009): Social services for senior citizens in Egypt. Cairo

32. ${ }^{x x x i i}$ Abdel-Moneim A (2003): Companion-ship marriage challenges and the age barrier. ElSharq al-Awsat journal - no. 8989, $9^{\text {th }}$ of July issue

33. ${ }^{x x x i i i}$ Farid TM and Mohammedin AS (2016) بlderly healthcare in Egypt باب الرعاية الصحية في مصر Pp.203-257 (54) in Zaki NG: Healthcare older. National Center for Social and Criminological Research (NCSCR), Cairo (in Arabic) ISBN 9789773093174

34. ${ }^{\text {xxiv }}$ Hegazy, E (2017): Civil society - analytical and critical studies. Revised by Inas alJAfaraawy. National Center for Social and Criminological Research (NCSCR), Cairo (in Arabic) ISBN 9789773093358 